\title{
Pengaruh Faktor-Faktor Budaya Organisasi Terhadap Kepuasan Kerja Pegawai Pada Kantor Pemerintah Daerah Kabupaten Karimun \\ Oleh :
}

\author{
${ }^{1}$ Roli Sambuardi, ${ }^{2}$ Fauzan Haqiqi, ${ }^{3}$ Azmi \\ ${ }^{1}$ Program Studi Ilmu Administrasi Negara, Fakultas Ilmu Sosial Dan Humaniora \\ Universitas Karimun \\ ${ }^{2}$ Program Studi Akuntansi, Fakultas Ilmu Sosial Dan Humaniora Universitas \\ Karimun \\ ${ }^{3}$ Program Studi Ilmu Administrasi Negara, Fakultas Ilmu Sosial Dan Humaniora \\ Universitas Karimun \\ Email: ${ }^{1}$ rolis4mbuardi@gmail.com, ${ }^{2}$ fauzanhaqiqi.1986@gmail.com, \\ 3alazzamazmi@gmail.com.
}

\begin{abstract}
Abstrak
Penelitian ini dilaksanakan dengan obyek Kantor Pemerintah Daerah Kabupaten Karimun, dengan melibatkan responden yang merupakan pegawai pada Kantor Pemerintah Daerah Kabupaten Karimun yang berjumlah 37 orang. Tujuan penelitian ini adalah untuk menganalisis pengaruh nilai-nilai budaya organisasi baik secara simultan maupun parsial terhadap tingkat kepuasan kerja pegawai Kantor Pemerintah Daerah Kabupaten Karimun. Disamping itu terdapat variabel yang paling dominan berpengaruh terhadap kepuasan kerja pegawai. Variabel dalam penelitian ini meliputi delapan variabel bebas yang terdiri dari Asas Tujuan, Asas Keunggulan, Asas Konsensus, Asas Kesatuan, Asas Prestasi, Asas Empirisme, Asas Keakraban, Asas Integritas, Serta satu variabel terikat yaitu kepuasan kerja pegawai. Pengujian hipotesis menghasilkan bahwa asas integritas mempunyai pengaruh yang paling dominan terhadap kepuasan kerja Pegawai Kantor Pemerintah Daerah Kabupaten Karimun. Hal ini ditunjukkan dengan nilai thitung adalah sebesar 6.521 dengan tingkat signifikansi sebesar 0.000 lebih besar dari $t_{\text {tabel }}$ sebesar 2.045. Hal ini menunjukkan bahwa terjadi penolakan Ho dan penerimaan Ha yang berarti terdapat pengaruh yang signifikan variabel asas integritas terhadap variabel kepuasan kerja Pegawai Kantor Pemerintah Daerah Kabupaten Karimun (Y). Nilai thitung ini dinyatakan paling besar dibandingkan variabelvariabel yang lain.
\end{abstract}

Kata Kunci: Budaya Organisasi, Kepuasan Kerja

\begin{abstract}
This research was conducted with the object of the Regional Government Office of Karimun Regency, involving respondents who were employees of the Regional Government Office of Karimun Regency, amounting to 37 people. The purpose of this study was to analyze the effect of organizational culture values both simultaneously and partially on the level of job satisfaction of employees of the Regional Government Office of Karimun Regency. Besides that, there is the most dominant variable influencing employee job satisfaction. The variables in this study include eight independent variables consisting of the Principle of Purpose, Principle of Excellence, Principle of Consensus, Principle of Unity, Principle of Achievement, Principle of Empiricism, Principle of Familiarity, Principle of Integrity, and one dependent variable namely employee job satisfaction. Hypothesis testing results in that the principle of integrity has the most dominant influence on job satisfaction of Karimun Regency Government Office Employees. This is indicated by the tcount value of 6,521 with a significance level of 0,000 greater than the table of 2,045. This shows that there is a rejection of Ho and Ha acceptance, which means there is a significant influence of the integrity principle variable on the job satisfaction variable of the Employees of the Regional Government Office of Karimun Regency (Y). This t-count value is stated to be the largest compared to the other variables.
\end{abstract}

Keywords: Organizational Culture, Job Satisfaction 
Japs: Jurnal Administrasi Politik dan Sosial, Vol. 1 No 2, Agustus 2020

P_ISSN: 2722-161X e_ISSN: 2722-1601

https://japs.ejournal.unri.ac.id/index.php/JAPS

\section{Pengaruh Faktor-Faktor Budaya Organisasi Terhadap Kepuasan Kerja}

Pegawai Pada Kantor Pemerintah Daerah Kabupaten Karimun

\section{PENDAHULUAN}

Persiapan lembaga pemerintahan yang baik dalam menghadapi era globalisasi, maka diperlukan berbagai langkah seperti pembenahan strategi dan sumber daya yang mendukung proses pelayanan publik, sehingga lembaga mampu menghasilkan output yang terbaik. Dalam hal ini, salah satu sumber daya strategis yang perlu memperoleh perhatian pembenahan adalah faktor sumber daya manusia atau pegawai .

Kualitas sumber daya manusia adalah kunci utama untuk dapat mencapai output yang terbaik sesuai dengan tujuan utama sebuah lembaga. Untuk mencapai kualitas sumber daya manusia tinggi, disamping peningkatan pengetahuan dan ketrampilan kerja pegawai (knowledge and skill of work), tidak kalah penting pula perlu dibangun sikap kerja (work attitude). Karena sikap kerja yang positif akan lebih mudah mendorong mereka menuju tercapainya produktifitas dan kreatifitas kerja yang lebih tinggi, yang semuanya ini sangat penting dalam menghadapi persaingan bisnis.

Ivancevich (dalam Manahan P. Tampubolon, 2004) mengatakan bahwa di dalam manajemen keragaman budaya yang merupakan penentu akhir suatu budaya organisasi. Suatu budaya yang terbentuk di dalam organisasi terdiri dari pembentukan dimensi-dimensi kepentingan budaya individu, sehingga untuk mengembangkan budaya organisasi ke arah positif maka diperlukan sistem pengelolaan manajemen, agar arah pemebentukan budaya itu terkendali dan menjadi modal utama bagi organisasi dan anggota-anggotanya berperilaku dan bertindak.

Kondisi seperti inilah yang menggambarkan suatu budaya dalam organisasi, baik itu organisasi bisnis, produksi atau jasa yang disebut sebagai budaya organisasi (corporate cukture). Demikian juga di dalam organisasi sosial dan organisasi yang menyangkut kemasyarakatan serta organisasi kenegaraan yang umumnya dikatakan sebagai kebudayaan.

Budaya organisasi merupakan bagian yang tidak terpisahkan dari lingkungan internal organisasi, karena keragaman budaya yang ada dalam suatu organisasi sama banyaknya dengan jumlah individu yang ada di dalam organisasi. Setiap pegawai mempunyai ciri dan karakteristik budaya masing-masing sehingga tidak tertutup kemungkinan ada pegawai yang tidak menyukai, tetapi ada juga 
Japs: Jurnal Administrasi Politik dan Sosial, Vol. 1 No 2, Agustus 2020

P_ISSN: 2722-161X e_ISSN: 2722-1601

https://japs.ejournal.unri.ac.id/index.php/JAPS

yang menyukai, sehingga diperlukan penyatuan persepsi dari seluruh pegawai atas pernyataan budaya organisasi.

Sedangkan Manahan P. Tampubolon (2004:187) bahwa budaya organisasi merupakan suatu nilai-nilai kunci yang dipercayai, serta pengertian dari karakteristik yang diberikan anggota kepada suatu organisasi. Budaya menjadi dasar orientasi bagi karyawan untuk memperhatikan kepentingan semua karyawan. Pengertiannya, bahwa budaya organisasi merupakan kumpulan dari budaya-budaya dan kepribadian dari anggota organisasi, menjadi suatu kesatuan budaya atau yang menggambarkan budaya sebuah organisasi. Budaya organisasi secara psikologis dapat menjadi motivasi bagi karyawan dalam bekerja, karena lingkungan budaya yang ada sesuai dengan budaya karyawannya. Budaya organisasi organisasi dapat digambarkan sebagai pakaian bagi organisasi untuk berhadapan dengan unsur-unsur di luar organisasi.

Beberapa penelitian empiris menunjukkan bahwa ketidakpuasan kerja cenderung membawa pengaruh negatif bagi organisasi. Karyawan-karyawan yang mengalami ketidakpuasan kerja dapat memanifestasikan ketidakpuasannya dengan macam-macam cara yang dapat mengarah ke perilaku kontraproduktif, protes, absensi dan bentuk-bentuk pengurangan input kerja lainnya. Bahkan sabotase dan pengunduran diri adalah bentuk lain dari manifestasi ketidakpuasan kerja yang dapat terjadi. Selanjutnya Manahan P. Tampubolon (2004) mengatakan bahwa secara garis besar salah satu aspek kepuasan kerja diperlihatkan dari ukuran respons dan sikap terhadap lingkungan kerja. Karena lingkungan kerja merupakan unsur budaya organisasi yang telah disepakati bersama menjadi suatu ciri budaya di antara sesama karyawan. Kemudian Menurut Fauzan Haqiqi (2020) menunjukkan Pemberian Modal Kerja dan Biaya Produksi berpengaruh signifikan terhadap Peningkatan Pendapatan Usaha Kecil Menengah di Desa Pongkar Kecematan Tebing Kabupaten Karimun

Menurut Wexly dan Yukl (2007), kepuasan kerja adalah sikap dan perasaan seseorang terhadap pekerjaan. Kepuasan kerja sangat diperlukan dan penting artinya bagi organisasi karena setiap karyawan yang merasa puas diharapkan akan dapat bekerja pada tingkat kapasitas penuh (full capacity). Dengan cara kerja yang demikian diharapkan akan dapat meningkatkan kinerja karyawan. Sebaliknya, jika karyawan tidak merasa puas dengan pekerjaannya maka akan terjadi kondisi penurunan kinerja mereka. Selanjutnya Menurt Azmi (2020) penelitian ini bahwa pelaksanaan Legislasi DPRD Kabupaten Karimun Periode 2014 - 2019 dalam proses penyusunan peraturan daerah Kabupaten/Kota di Sekretariat DPRD Kabupaten Karimun dengan langkah-langkah, yaitu: Perencanaan Peraturan 
Japs: Jurnal Administrasi Politik dan Sosial, Vol. 1 No 2, Agustus 2020

P_ISSN: 2722-161X e_ISSN: 2722-1601

https://japs.ejournal.unri.ac.id/index.php/JAPS

Daerah, Penyusunan Rancangan Peraturan Daerah, Pengesahan dan Penetapan, Pengudangan.

Ketidakpuasan dapat memunculkan perilaku penarikan diri atau perilaku agresif seperti, sabotase, kesalahan yang disengaja, pemogokan dan sebagainya. Kondisi ini tentunya dapat mempengaruhi menurunnya kinerja karyawan yang akhirnya akan sangat merugikan organisasi yang terkait. Menurut Robbins (2008), karyawan akan mengekspresikan bentuk ketidakpuasannya melalui empat cara yaitu: 1) keluar dari pekerjaannya dan mencari pekerjaan baru, 2) bekerja dengan seenaknya (datang terlambat, tidak masuk kerja, membuat kesalahan yang disengaja), 3) membicarakan ketidakpuasannya dengan tujuan agar kondisi tersebut berubah, 4) menunggu dengan optimis bahwa organisasi dan manajemennya dapat melakukan sesuatu yang lebih baik. Dalam hal ini, kepuasan kerja sangat berkaitan erat dengan nilai-nilai budaya yang berlaku di organisasi (Atmosoeprapto, 2000). Penjelasan pangkalnya adalah bahwa kepuasan karyawan (employee satisfaction) dipengaruhi oleh kualitas perlakuan organisasi terhadap karyawan. Sementara kualitas perlakuan organisasi mencerminkan budaya organisasi yang ada di organisasi.

Budaya nasional suatu bangsa umumnya akan memberikan pengaruh terhadap budaya organisasi. Walaupun budaya organisasi tidak $100 \%$ dipengaruhi oleh budaya nasional dari suatu bangsa, tetapi budaya nasional memberikan pengaruh yang cukup kuat terhadap budaya organisasi, karena sesungguhnya organisasi terdiri dari orang-orang yang di dalam dirinya terdapat budaya nasional suatu bangsa. Budaya organisasi merupakan kumpulan nilai, harapan serta kebiasaan masing-masing orang yang ada di organisasi tersebut, yang pada umumnya tetap dipertahankan dari satu generasi ke generasi berikutnya. Manajemen puncak harus ekstra hati-hati dalam mempertimbangkan budaya organisasi ini saat menganalisis faktor strategis internal karena kadang-kadang faktor strategis internal tersebut bertentangan dengan budaya organisasi yang ada sehingga kurang mendapat dorongan dan dukungan dari para karyawan.

Budaya organisasi menjadi suatu hal yang sangat penting untuk dipahami. Diyakini juga bahwa budaya organisasi yang kuat serta nilai-nilai budaya organsasi yang dipegang secara kuat oleh anggota organisasi akan menimbulkan kinerja yang baik. Pada umumnya, dari hasil audit manajemen yang dilakukan dalam aktivitas yang dilakukan di dalam organisasi, hal tersebut dapat digunakan untuk menjaga kesinambungan operasional dari para manajer atau ahli sumber daya manusia, serta mengikuti kebijaksanaan dalam mengembangkan efektivitas sumber daya manusia. Kontribusi sumber daya manusia dalam organisasi akan dapat memenuhi kebutuhan hidup individu serta kelanjutan organisasi. Sumber 
Japs: Jurnal Administrasi Politik dan Sosial, Vol. 1 No 2, Agustus 2020

P_ISSN: 2722-161X e_ISSN: 2722-1601

https://japs.ejournal.unri.ac.id/index.php/JAPS

daya manusia mempunyai prospek sebagai individu dan sebagai bagian dari masyarakat yang berkelanjutan. Di samping itu tantangan individu sebagai sumber daya manusia yang profesional, yang harus secara konsisten dapat meningkatkan efektifitas keprofesionalannya harus tetap mengantisipasi pencapaian sasaran dan tujuan dari organisasi. Setiap perubahan yang terjadi harus terus diikuti individu di dalam organisasi, agar perubahan tersebut dapat diantisipasi. Setiap perubahan di dalam organisasi dapat membuat perubahan di dalam profesionalisme individu. Sebagai profesionalisme individu juga harus siap menerima perubahan dan membuat perubahan di dalam budaya organisasi.

\section{METODE PENELITIAN}

Pendekatan yang digunakan dalam Penelitian ini adalah penelitian kuantitatif dengan pendekatan deskriptif. Metode penelitian kuantitatif merupakan salah satu jenis penelitian yang spesifikasinya adalah sistematis, terencana dan terstruktur dengan jelas sejak awal hingga pembuatan desain penelitiannya. Menurut Sugiyono (2013: 13), metode penelitian kuantitatif dapat diartikan sebagai metode penelitian yang berlandaskan pada filsafat positivisme, digunakan untuk meneliti pada populasi atau sampel tertentu, teknik pengambilan sampel pada umumnya dilakukan secara random, pengumpulan data menggunakan instrumen penelitian, analisis data bersifat kuantitatif/statistik dengan tujuan untuk menguji hipotesis yang telah ditetapkan. Penelitian ini menggunakan pendekatan deskriptif dengan tujuan untuk mendeskripsikan objekpenelitian atupun hasil penelitian. Adapun pengertian deskriptif menurut Sugiyono (2012: 29) adalah metode yang berfungsi untuk mendeskripsikan atau memberi gambaran terhadap objek yang diteliti melalui data atau sampel yang telah terkumpul sebagimana adanya, tanpa melakukun analisis dan membuat kesimpulan yang berlaku umum.

\section{HASIL DAN PEMBAHASAN}

\section{Hasil Validitas}

Instrumen disebarkan kepada 37 responden dan dalam pengujian ini koefisien kolerasi product moment kritis diperoleh dari tabel ditribusi $\mathrm{r}$ dengan menggunakan derajat bebas $(\mathrm{N}-2)=23-2=21$ dan taraf signifikan sebesar 5\% diperoleh nilai r-tabel sebesar 0.329 . Jika kuesioner validitas butir pernyataan sama atau lebih besar dari koefisien validitas kritis (tabel), maka butir pernyataan dinyatakan valid, tetapi jika koefisien validitas, butir pernyataan lebih kecil dari koefisien validitas kritis (tabel ) maka butir pernyataan tersebut dinyatakan tidak valid (gugur). Selanjutnya butir pernyataan yang tidak valid (gugur) dikeluarkan atau tidak dipakai dalam analisa data. 
Japs: Jurnal Administrasi Politik dan Sosial, Vol. 1 No 2, Agustus 2020

P_ISSN: 2722-161X e_ISSN: 2722-1601

https://japs.ejournal.unri.ac.id/index.php/JAPS

\section{Asas Tujuan}

Hasil pengujian validitas instrumen asas tujuan dengan menggunakan kolerasi product moment yang ditunjukkan pada tabel berikut :

Tabel 1.1 Hasil Uji Validitas Asas Tujuan

\begin{tabular}{cccc}
\hline No. Butir & rhitung & rtabel & Status \\
\hline 1 & 0.477 & 0.329 & Valid \\
2 & 0.817 & 0.329 & Valid \\
3 & 0.659 & 0.329 & Valid \\
4 & 0.657 & 0.329 & Valid \\
5 & 0.562 & 0.329 & Valid \\
\hline
\end{tabular}

Sumber : data primer, diolah

Validitas ini ditunjukkan oleh nilai $r_{h i t u n g}$ yang lebih besar dari nilai $r_{\text {tabel. }}$. Dari tabel di atas dapat diketahui bahwa semua butir pertanyaan dinyatakan valid, maka untuk selanjutnya keseluruhan butir-butir pertanyaan ini dapat digunakan untuk analisa regresi.

\section{Asas Konsensus}

Hasil pengujian validitas instrumen asas konsensus dengan menggunakan kolerasi product moment yang ditujukkan pada tabel berikut :

Tabel 2.1 Hasil Uji Validitas Asas Konsensus

\begin{tabular}{cccc}
\hline No. Butir & r hitung & r tabel & Status \\
\hline 1 & 0.944 & 0.329 & Valid \\
2 & 0.949 & 0.329 & Valid \\
3 & 0.901 & 0.329 & Valid \\
4 & 0.864 & 0.329 & Valid \\
5 & 0.911 & 0.329 & Valid \\
\hline
\end{tabular}

Sumber : data primer, diolah

Validitas ini ditunjukkan oleh nilai $r_{\text {hitung }}$ yang lebih besar dari nilai $r_{\text {tabel. }}$. Dari tabel di atas dapat diketahui bahwa semua butir pertanyaan dinyatakan valid, maka untuk selanjutnya keseluruhan butir-butir pertanyaan ini dapat digunakan untuk analisa regresi.

\section{Asas Keunggulan}

Hasil pengujian validitas instrumen asas keunggulan dengan menggunakan kolerasi product moment yang ditujukkan pada tabel berikut :

Tabel 3.1 Hasil Uji Validitas Asas Keunggukan

\begin{tabular}{cccc}
\hline No. Butir & rhitung & rtabel & Status \\
\hline 1 & 0.752 & 0.329 & Valid \\
2 & 0.649 & 0.329 & Valid \\
3 & 0.539 & 0.329 & Valid \\
4 & 0.797 & 0.329 & Valid \\
\hline
\end{tabular}

Sumber : data primer, diolah 
Japs: Jurnal Administrasi Politik dan Sosial, Vol. 1 No 2, Agustus 2020

P_ISSN: 2722-161X e_ISSN: 2722-1601

https://japs.ejournal.unri.ac.id/index.php/JAPS

Validitas ini ditunjukkan oleh nilai $r_{\text {hitung }}$ yang lebih besar dari nilai $r_{\text {tabel. }}$ Dari tabel di atas dapat diketahui bahwa semua butir pertanyaan dinyatakan valid, maka untuk selanjutnya keseluruhan butir-butir pertanyaan ini dapat digunakan untuk analisa regresi.

\section{Asas Kesatuan}

Hasil pengujian validitas instrumen asas kesatuan dengan menggunakan kolerasi product moment yang ditujukkan pada tabel berikut :

Tabel 4.1 Hasil Uji Validitas Asas Kesatuan (X4)

\begin{tabular}{|c|c|c|c|}
\hline No. Butir & rhitung & rtabel & Status \\
\hline 1 & 0.944 & 0.329 & Valid \\
\hline 2 & 0.949 & 0.329 & Valid \\
\hline 3 & 0.901 & 0.329 & Valid \\
\hline 4 & 0.864 & 0.329 & Valid \\
\hline 5 & 0.911 & 0.329 & Valid \\
\hline
\end{tabular}

Sumber : data primer, diolah

Validitas ini ditunjukkan oleh nilai $\mathrm{r}_{\text {hitung }}$ yang lebih besar dari nilai $\mathrm{r}_{\text {tabel }}$. Dari tabel di atas dapat diketahui bahwa semua butir pertanyaan dinyatakan valid, maka untuk selanjutnya keseluruhan butir-butir pertanyaan ini dapat digunakan untuk analisa regresi.

\section{Asas Prestasi}

Hasil pengujian validitas instrumen asas prestasi dengan menggunakan kolerasi product moment yang ditujukkan pada tabel berikut :

Tabel 5.1 Hasil Uji Validitas Asas Prestasi

\begin{tabular}{cccc}
\hline No. Butir & rhitung & rtabel & Status \\
\hline 1 & 0.645 & 0.329 & Valid \\
2 & 0.897 & 0.329 & Valid \\
3 & 0.395 & 0.329 & Valid \\
4 & 0.733 & 0.329 & Valid \\
5 & 0.631 & 0.329 & Valid \\
6 & 0.850 & 0.329 & Valid \\
\hline
\end{tabular}

\section{Sumber : data primer, diolah}

Validitas ini ditunjukkan oleh nilai $r_{\text {hitung }}$ yang lebih besar dari nilai $r_{\text {tabel }}$. Dari tabel di atas dapat diketahui bahwa semua butir pertanyaan dinyatakan valid, maka untuk selanjutnya keseluruhan butir-butir pertanyaan ini dapat digunakan untuk analisa regresi.

\section{Asas Empirik}

Hasil pengujian validitas instrumen asas empirik dengan menggunakan kolerasi product moment yang ditujukkan pada tabel berikut : 
Japs: Jurnal Administrasi Politik dan Sosial, Vol. 1 No 2, Agustus 2020

P_ISSN: 2722-161X e_ISSN: 2722-1601

https://japs.ejournal.unri.ac.id/index.php/JAPS

Tabel 5.1 Hasil Uji Validitas Asas Empirik (X6)

\begin{tabular}{cccc}
\hline $\begin{array}{c}\text { No. } \\
\text { Butir }\end{array}$ & rhitung & rtabel & Status \\
1 & 0.814 & 0.329 & Valid \\
2 & 0.776 & 0.329 & Valid \\
3 & 0.860 & 0.329 & Valid \\
4 & 0.694 & 0.329 & Valid \\
5 & 0.844 & 0.329 & Valid \\
6 & 0.724 & 0.329 & Valid \\
\hline
\end{tabular}

Sumber : data primer, diolah

Validitas ini ditunjukkan oleh nilai $r_{\text {hitung }}$ yang lebih besar dari nilai $r_{\text {tabel. }}$. Dari tabel di atas dapat diketahui bahwa semua butir pertanyaan dinyatakan valid, maka untuk selanjutnya keseluruhan butir-butir pertanyaan ini dapat digunakan untuk analisa regresi.

\section{Asas Keakraban}

Hasil pengujian validitas instrumen asas keakraban dengan menggunakan kolerasi product moment yang ditujukkan pada tabel berikut :

Tabel 7.1 Hasil Uji Validitas Asas Keakraban

\begin{tabular}{cccc}
\hline No. Butir & rhitung & rtabel & Status \\
\hline 1 & 0.714 & 0.329 & Valid \\
2 & 0.807 & 0.329 & Valid \\
3 & 0.828 & 0.329 & Valid \\
4 & 0.853 & 0.329 & Valid \\
\hline
\end{tabular}

\section{Sumber : data primer, diolah}

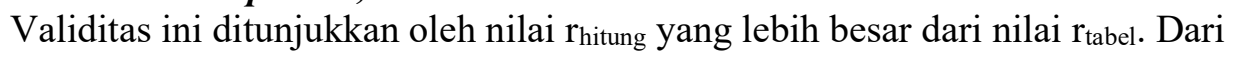
tabel di atas dapat diketahui bahwa semua butir pertanyaan dinyatakan valid. Maka untuk selanjutnya keseluruhan butir-butir pertanyaan ini dapat digunakan untuk analisa regresi

\section{Asas Integritas}

Hasil pengujian validitas instrumen asas integritas dengan menggunakan kolerasi product moment yang ditujukkan pada tabel berikut :

\section{Tabel 8.1 Hasil Uji Validitas Asas Integritas (X8)}

\begin{tabular}{|c|c|c|c|}
\hline No. Butir & $\mathrm{r}_{\text {hitung }}$ & $\mathrm{r}_{\text {tabel }}$ & Status \\
\hline 1 & 0.734 & 0.334 & Valid \\
\hline 2 & 0.910 & 0.334 & Valid \\
\hline 3 & 0.676 & 0.334 & Valid \\
\hline 4 & 0.622 & 0.334 & Valid \\
\hline 5 & 0.757 & 0.334 & Valid \\
\hline
\end{tabular}

\section{Sumber : data primer, diolah}

Validitas ini ditunjukkan oleh nilai $r_{\text {hitung }}$ yang lebih besar dari nilai $r_{\text {tabel. }}$ Dari tabel di atas dapat diketahui tidak semua butir pertanyaan dinyatakan valid, ada satu butir pertanyaan yang dinyatakan tidak valid karena nilai $r_{\text {hitung }}$ lebih 
Japs: Jurnal Administrasi Politik dan Sosial, Vol. 1 No 2, Agustus 2020

P_ISSN: 2722-161X e_ISSN: 2722-1601

https://japs.ejournal.unri.ac.id/index.php/JAPS

kecil dari $r_{\text {tabel}}$, maka untuk selanjutnya keseluruhan butir-butir pertanyaan ini dapat digunakan untuk analisa regresi.

\section{Kepuasan Kerja Pegawai}

Hasil pengujian validitas instrumen asas prestasi dengan menggunakan kolerasi product moment yang ditujukkan pada tabel berikut :

Tabel 9.1 Hasil Uji Validitas Budaya Organisasi (Y)

\begin{tabular}{cccc}
\hline No. Butir & rhitung & rtabel & Status \\
\hline 1 & 0.616 & 0.329 & Valid \\
2 & 0.634 & 0.329 & Valid \\
3 & 0.663 & 0.329 & Valid \\
4 & 0.738 & 0.329 & Valid \\
5 & 0.624 & 0.329 & Valid \\
6 & 0.625 & 0.329 & Valid \\
7 & 0.532 & 0.329 & Valid \\
8 & 0.591 & 0.329 & Valid \\
9 & 0.784 & 0.329 & Valid \\
10 & 0.478 & 0.329 & Valid \\
11 & 0.791 & 0.329 & Valid \\
12 & 0.659 & 0.329 & Valid \\
13 & 0.748 & 0.329 & Valid \\
\hline
\end{tabular}

Sumber : data primer, diolah

Validitas ini ditunjukkan oleh nilai $r_{\text {hitung }}$ yang lebih besar dari nilai $r_{\text {tabel}}$.

Dari tabel di atas dapat diketahui bahwa semua butir pertanyaan dinyatakan valid, maka untuk selanjutnya butir-butir pertanyaan yang dinyatakan valid dapat digunakan untuk analisa regresi.

\section{Analisis Pembahasan}

Penelitian ini menemukan bahwa semua dari delapan dimensi-dimensi budaya organisasi akan mempengaruhi ke puasan kerja Pegawai Kantor Pemerintah Daerah Kabupaten Karimun. Hasil analisa menemukan bahwa yang mempengaruhi kepuasan kerja Pegawai adalah aspek tujuan, aspek keunggulan, aspek konsensus, aspek kesatuan. Selanjutnya hasil analisa, bahwa yang mempunyai pengaruh paling dominan dari dimensi-dimensi budaya organisasi terjadap kepuasan kerja Pegawai adalah asas integritas. Asas integritas meliputi; tindakan-tindakan atasan yang menunjukkan bahwa organisasi ini memperhatikan kepentingan para pegawai, atasan beranggapan bahwa semua pegawai berhak dan boleh menyumbangkan pendapat dalam proses pengambilan keputusan, Pegawai sadar dan berniat di waktu yang akan datang harus bekerja dengan lebih baik, perasaan Pegawai tentang perolehan informasi yang berkaitan dengan 
Japs: Jurnal Administrasi Politik dan Sosial, Vol. 1 No 2, Agustus 2020

P_ISSN: 2722-161X e_ISSN: 2722-1601

https://japs.ejournal.unri.ac.id/index.php/JAPS

pekerjaannya, kesempatan untuk memperluas pengetahuannya di organisasi ini melalui kerjasama dengan pegawai lainnya.

Penemuan penelitian ini tidak berbeda dengan penelitian Moh Masrur (2003) yang menemukan bahwa dimensi budaya organisasi yang berpengaruh terhadap kepuasan kerja adalah asas keunggulan. Perlu dipahami bahwa berbeda organisasi atau dinas maka berbeda pula budaya yang ada dalam organisasi atau tersebut. Terutama obyek yang dijadikan penelitian ini adalah Pegawai Negeri Sipil yang memepunyai karakteristik tertentu yang dapat membentuk buadaya organisasi. Miller (2007, dalam Talizinduhu Ndraha, 2009) mengemukakan bahwa asas integritas menyangkut sejauhmana prinsip kebenaran, kejujuran dan kepercayaan menjadi dasar atas sikap dan perilaku pimpinan serta hubunganhubungan organisasional dalam dinas. Penerapan asas ini akan tercermin pada praktis menyatukan kata dengan perbuatan dan juga akan terekspresikan pada kesungguhan pimpinan maupun pegawai dalam usaha pencapaian tujuan Kantor Pemerintah Daerah Kabupaten Karimun.

\section{KESIMPULAN}

Berdasarkan hasil penelitian yang telah dilakukan maka dapat diambil kesimpulan sebagai berikut :

1. Terdapat pengaruh yang signifikan antara dimensi-dimensi budaya organisasi (aspek tujuan, aspek keunggulan, aspek konsensus, aspek kesatuan, aspek prestasi, aspek empirisme, aspek keakraban, dan aspek integritas) secara besama-sama terhadap tingkat budaya organisasi. Hal ini ditunjukkkan dengan nilai menghasilkan nilai $F_{\text {hitung }}$ sebesar 63,898 dan $F_{\text {tabel }}$ sebesar 2.19. Dengan demikian maka terbukti bahwa $F_{\text {hitung }}$ lebih besar daripada $F_{\text {tabel }}$ yang berarti Ho ditolak dan menerima Ha pada tingkat signifikansi sebesar 0.000.

2. Semua dari dimensi-dimensi budaya organisasi yang terdiri dari aspek tujuan, aspek keunggulan, aspek konsensus, aspek kesatuan, aspek prestasi, aspek empirisme, aspek keakraban, dan aspek integritas berpengaruh secara parsial terhadap kepuasan kerja Pegawai Kantor Pemerintah Daerah Kabupaten Karimun.

3. Pengujian hipotesis menghasilkan bahwa asas integritas mempunyai pengaruh yang paling dominan terhadap kepuasan kerja Pegawai Kantor Pemerintah Daerah Kabupaten Karimun. Hal ini ditunjukkan dengan nilai thitung adalah sebesar 6.521 dengan tingkat signifikansi sebesar 0.000 lebih besar dari $t_{\text {tabel }}$ sebesar 2.045. Hal ini menunjukkan bahwa terjadi penolakan Ho dan penerimaan Ha yang berarti terdapat pengaruh yang signifikan variabel asas integritas terhadap variabel kepuasan kerja Pegawai Kantor Pemerintah 
Japs: Jurnal Administrasi Politik dan Sosial, Vol. 1 No 2, Agustus 2020

P_ISSN: 2722-161X e_ISSN: 2722-1601

https://japs.ejournal.unri.ac.id/index.php/JAPS

Daerah Kabupaten Karimun (Y). Nilai thitung ini dinyatakan paling besar dibandingkan variabel-variabel yang lain.

\section{DAFTAR PUSTAKA}

Gibson, Ivansevich, and Donelly.(2001). Organisasi, Jilid 1. Penerbit: Erlangga, Jakarta.

Hasibuan, Melayu, SP. (2003). Manajemen Sumber Daya Manusia. Jakarta : Toko Gunung Agung.

Irwanto, dkk. (2009). Psikologi Umum. Buku Panduan Mahasiswa, Jakarta. PT. Gramedia.

Kartono, Kartini. (2000). Pemimpin dan Kepemimpinan. Jakarta : Rajawali Fress. Kuncoro, Mudrajat. (2003). Metode Riset untuk Bisnis dan Ekonomi. Penerbit Erlangga, Jakarta.

Nurgiyantoro, B., Gunawan, \& Marzuki. (2000). Statistik Terapan Untuk Penelitian Ilmu-ilmu Sosial. Gajah Mada University Press, Yogyakarta.

Robbins, Stephen P. (2003). Perilaku Organisasi, Jilid 1, 2. Penerbit : PT. Indeks Kelompok Gramedia, Jakarta.

Slameto, Agus, (1988). Psikologi Industri. Penerbit Sinar Buku Baru, Bandung Pareek, A. (2001). Psychology in Industry. Englewood: Prentice-Hall Inc, New York.

Sugiyono. (2009). Statistik Untuk Penelitian. Bandung : CV Alfabeta

Timpe, A. Dale, (2001). Kepemimpinan. Seri Manajemen Sumber Daya Manusia, Terjemahan Susanto Boedidharmo, Penerbit : Elex Media Komputindo, Jakarta.

Vitasari. (2002). Komitmen dalam Manajemen Sumber Daya Manusia. http://www/mss-feui.cjb.net.

White, Ralph and Ronald Lipiit. (2000). Autocracy and Democracy. Harper \& Row Publisher Inc.

Fauzan Haqiqi, Rahma Dewi Susanti and Ferawati 2020. Analisis Pengaruh Pemberian Modal Kerja Dan Biaya Produksi Terhadap Peningkatan Pendapatan Usaha Kecil Menengah Di Desa Pongkar Kecamatan Tebing Kabupaten Karimun (Tahun 2014 - 2018). Jurnal Cafetaria. 1, 1 (Jan. 2020), 63-72.

Azmi, A., \& M. Kurniawan , M. K. (2020). Pelaksanaan Legislasi DPRD Kabupaten Karimun ( Studi Pembentukan Perda Periode 2018 ).

Jurnal kemunting, 1(1), 118-132. Retrieved from http://www.ejurnal.universitaskarimun.ac.id/index.php/IAN/article/view/3 